\title{
Impact of Ustilaginoidea virens mycotoxins on rice seed germination and their feeding risk
}

\author{
Mona M. Saleh ${ }^{1}$ (D) and Nour El-Hoda A. Zidan² \\ Address: \\ 1 Plant Pathology Research Institute, Agricultural Research Center, Giza, Egypt. \\ 2 Pesticides Chemistry and Toxicology Dept., Fac. Agric., Kafrelsheikh Univ.,33516, Kafr El-Sheikh, Egypt \\ *Corresponding author: Mona M. Saleh, habebanna@yahoo.com \\ Received: 3-11-2020; Accepted: 22-12-2020; Published: 26-12-2020
}

\section{ABSTRACT}

Rice false smut (RFSm) disease caused by Ustilaginoidea virens (Cooke) Takah (teleomorph: Villosiclava virens) has become one of the most devastating rice diseases all over the world. The pathogen is known to produce secondary metabolites i.e. ustiloxins which are known to be harmful to plant growth, human and domestic animals. This work had taken into consideration the effect of soaking seeds in either the pathogen spore suspension or rice false smut balls cell-free extract (RFSBCFE) on seed germination, shoot length and root length of nine rice cultivars. Seed germination \% ranged from 78.66 to 98.66 under soaking in spore suspension, however it ranged from 20 to 93.33 when seeds were soaked in RFSBCFE. Soaking rice grains of Sakha 104 in spore suspension, recorded the highest values in shoot and root length (5.23 and 5.80, respectively). While, Super 300, Sakha 108 and Sakha 104 cultivars showed the highest shoot and root length when their grains were soaked in RFSBCFE. Using LC-MS/MS method, five Ustiolxins ( $, B, C, D$ and F) have been detected in RFSBCFE. Finally, the toxic effect of using contaminated diets with rice false smut balls for feeding with five concentrations ( $0 \%, 1 \%, 5 \%, 10 \%$ and $25 \%$ (wt/wt)) has been studied on rats. RFSBs were found to be toxic for both kidney and liver of rats. Whereby biochemical parameters of liver functions, i.e. aspartate aminotransferase activity, alanine aminotransferase activity, albumin, and bilirubin levels and kidney functions (urea and creatinine concentration) were severely affected. Likewise, haematological indices were also influenced. On the other side, the lesions mentioned above were relatively obscure in concentration of $1 \%$.

Keywords: Rice False Smut, Phytotoxicity, Ustiloxins, LC-MS/MS, Feeding Risk

\section{INTRODUCTION}

In 1878, rice false smut (RFSm) disease, caused by the ascomycete fungus Ustilaginoidea virens (Cooke) Takah (teleomorph: Villosiclava virens) was firstly recognized in India by Cooke (Baite and Sharma, 2015). It was then a minor disease that appeared in sporadic rice fields. Now, excessive doses of nitrogenous fertilizers, extensive planting of hybrids and high-yielding cultivars with low disease resistant levels aided RFSm disease to become one of the most devastating rice diseases all over the world (Zhou et al., 2014). U. virens infects the young ovary of single spikelets and changes them at the late phase of infection into greenish spore balls with a velvety look (commonly known as smut balls or smut galls) filled with chlamydospores (Nessa, 2017). These smutted balls contaminate rice grains during harvest. While screening the balls can remove them from rough rice to minimize this problem, this is an expensive treatment, as well as the disease negatively affects the economic value of the product. On the other hand, these balls could be toxic to humans and animals. Two types of mycotoxins, ustiloxins and ustilaginoidins were found to be produced by the pathogen.

Ustiloxins are cyclic peptides, that are toxic to plants and animals by interfering with microtubule function, hence inhibiting mitosis (Takahashi et al., 2012; Li et al., 2013 and Lu et al., 2015). Both location and environmental conditions affect the type and amount of toxins produced by false smut balls. The pathogen could produce more than $100 \mathrm{mg} \mathrm{kg}^{-1}$ false smut balls of Ustiloxins (Koiso et al., 1994 ; Nakamura et al., 1994; Li et al., 1995). Ustiloxins group has different structures including ustiloxins A, B, C, D, E and F (Abbas, et al. 2014 ; Fu et al., 2017 and Lin et al., 2018). The content of ustiloxin A in rice grains ranges from 0.0073 to $4.33 \mu \mathrm{g} / \mathrm{g}$ (Ji et al., 2012); while ustiloxins A and B content is more higher in rice false smut balls, ranging from 0.13 to $1.08 \mathrm{mg} / \mathrm{g}$ (Shan et al., 2012 and Fu et al., 2015b). So, both rice false smut balls and false smut pathogen-contaminated rice food and forage were considerably looked by food and feed safety.

Accompanying climatic changes in Egypt, RFS has become a true problem in some rice cultivars, causing great damage in the yield. The danger of RFS is not only enclosed in the losses of yield but also in contaminating grains of rice and straw being poisonous for both human and animal (Li et al., 1995 and Shan et al., 2012). There is still inadequate evidence from hazard assessment to evaluate the risk of ustiloxins in food and feed is still (Xiaoxiang et al., 2015). However, few published studies concerning toxic effects of $U$. virens on both liver and kidney functions in non-target organisms are available. To our knowledge, the toxic effect of RFS disease on plants or animals was not previously studied in Egypt. So this study investigated the effect of spores or rice false smut balls cell-free extract (RFSBCFE) on seed germination and plant vigor as a result of RFS disease infection. Also, it detected toxins in RFS infected grains by LC-MS/MS. Besides, it checked the toxicity feeding of RFS contaminated grains on male albino rats as an indicator of polluted rice grains nutrition risk on human and ruminants health.

\section{MATERIAL AND METHODS}

Sample collection:

Panicles showing typical symptoms of rice false smut disease, caused by Ustilaginoidea virens (telemorph: Villosiclava virens), were collected from naturally infected rice fields at Sakha Agricultural Research Farm in Egypt.

Preparation of pure powdered spores of U.verins:

Rice false smut balls (RFSbs) were collected and left to dry till a constant weight at room temperature in shade. Air-dried balls were pulverized in an electric blender and screened through a sieve of $1 \mathrm{~mm}$-diameter for any debris to get the most possible pure powdered sample of the pathogen spores. The powdered sample was stored in plastic bags at $-20{ }^{\circ} \mathrm{C}$ till being used (Shan et al., 2012). 
Preparation of spore suspension and rice false smut balls cell-free extract (RFSBCFE):

According to Abbas et al. (2014), spore suspension of $U$. verins $\left(10^{8} \mathrm{spore} / \mathrm{ml}\right)$ and RFSBCFE were prepared. Both solutions were tested to their phytotoxicity effect on rice seed germination.

\section{Phytotoxicity test:}

This experiment was performed in a completely randomized design (CRD) at the laboratory. Twenty-five seeds of each of the nine different rice cultivars i.e., Sakha 101, Sakha 104, Sakha 108, Giza 171, Giza 178, Giza 181, Giza182 super 300 and Hybrid 1, were soaked (for 24h) separately in $20 \mathrm{ml}$ of either spore suspension or RFSBCFE in plastic bags to test their effects on seed germination (\%), shoot length and root length (Sanghera et al., 2012). Seeds soaked in sterilized water were used as a check treatment. After $24 \mathrm{~h}$, the spore suspension and/ or extract in plastic bags were drained off. Seeds were distributed in $12 \mathrm{~cm}$ Petri dishes, containing filter papers moistened with distilled sterilized water. Each plate contained 25 seeds. Three replicate plates were used for each treatment, and incubation was carried out at $30^{\circ} \mathrm{C}$. To enhance germination, the incubator was adjusted to be dark for the first three days. On the fourth day, plates were exposed to $12 \mathrm{hr}$ light/ $12 \mathrm{hr}$ dark. Along with the experiment, plates were supplied with sterile water as required to keep moisture. Seed germination percentage was recorded after 14 days for each plate (Nessa et al., 2018). While the length (cm) of shoot and root was measured after 21 days.

\section{Preparation of Crude Ustiloxin Extracts:}

According to Shan et al. (2013), the powdered sample of rice false smut spores (350 g) was extracted with deionized water (1L) at room temperature under ultrasound for $30 \mathrm{~min}$. A rotary evaporator under vacuum at $60{ }^{\circ} \mathrm{C}$ was used to concentrate the water solution and get rid of excessive water. The net extract was stored at $4^{\circ} \mathrm{C}$ until required.

\section{Toxin identification using LC-MS/MS:}

In Main Laboratory Chemical Warfare, Kilo 4.5, Almaza, Cairo, toxin detection was performed. The net extract sample was employed to LC-MS/MS as described by Lin et al., (2018) to detect toxins.

\section{Toxicity of rice false smut balls (RFSBs):}

To test the risk of feeding on RFSBs contaminated food, Adult male albino rats (Sprague-Dawely), Rattusnor vegicus var. albus, weighing 185-200 g were bought from the Biological Products \& Vaccines Holding Company, Helwan Farm, Cairo, Egypt. Rats were randomly grouped into five, including five rats for each. RFSBs were added to the diet at $0 \%, 1 \%, 5 \%, 10 \%$ and $25 \%$ (wt/wt). Rats behavior and any symptoms of toxicity or mortality were recorded during fourteen feeding administration days (Abbas et al., 1984), then rats were slaughtered. Livers and kidneys were weighed. Blood samples were immediately collected to assess some enzyme activities and the level of both kidney and liver function parameters, i.e. serum level of alanine aminotransferase (ALT), aspartate aminotransferase (AST), albumin, bilirubin, urea and creatinine. Also, complete blood count $(C B C)$, red blood cell count (RBC's), haemoglobin concentration (HGB), total platelet count (PLT), white blood cell count (WBC's), packed cell volume (PCV), mean cell volume of RBC's (MCV), mean cell haemoglobin (MCH), mean cell haemoglobin concentration (MCHC) for hematological examination, (Eissa and Zidan, 2010).

\section{Statistical analysis:}

The completely randomized design was applied to experiments. Means were compared using multiple range tests according to Duncan (1955) using computer program COSTAT.

\section{RESULTS}

\section{Sample collection:}

From naturally infected rice fields, panicles showing typical symptoms of false smut caused by Ustilaginoidea virens (Telemorph: Villosicalava virens) were collected and the galls were separated for further experiments as illustrated in Fig. $\mathbf{1}$ ( $\mathbf{A}$ and $\mathbf{B}$ ).

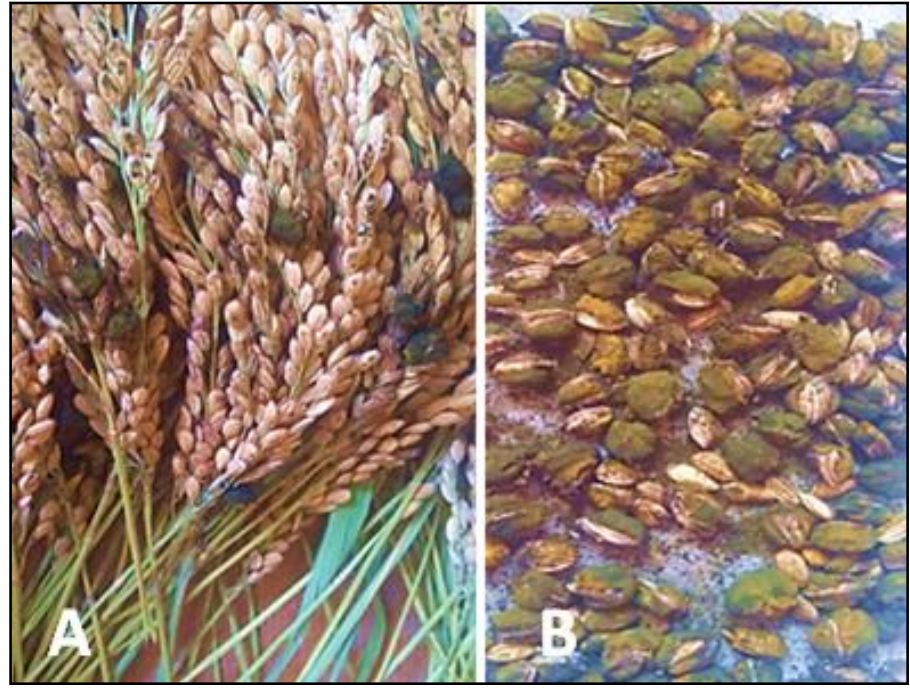

Fig. 1. Panicles naturally infected with rice false smut disease (A) and rice false smut balls (RFSbs) (B). 


\section{Phytotoxicity test:}

Results of seed soaking of nine rice cultivars in Ustilaginoidea virens spore suspension are presented in Table (1). All cultivars were affected by soaking in spore suspension whereas seed germination \% ranged from 78.66 to 98.66 in comparison with healthy ones that completely germinated. Giza 171 recorded the highest seed germination (98.66 \%) followed by Giza 178 that equalled Sakha 104 (97.33\%). Meanwhile, seed germination of Sakha 101 was $96 \%$. On the other hand, seed germination of Sakha 108 which also equalled Super 300 was $94.66 \%$. However, Giza 181 recorded the lowest seed germination (78.66\%).

Sakha 104 exceeded the other infected cultivars in length for both shoot and root $(5.23 \mathrm{~cm} \mathrm{\&} 5.80 \mathrm{~cm}$, respectively). Giza 171 , Giza 178 and Super 300 rice cultivars were the followings in shoot length, while Hybrid 1 and Giza 181 recorded the least values in this respect (2.22 \& 2.11cm, respectively). Although Giza 182 recorded 92\% seed germination, it followed Sakha 104 in root length. While Giza 171 recorded the highest seed germination \% and followed Giza 182 in root length. Nevertheless, Giza 182 and Hybrid 1 equalled in seed germination\% (92\%), Giza 182 roots were longer than Hybrid 1 (4.86 and $2.86 \mathrm{~cm}$, respectively). While Giza 181 was the least in all the measured parameters.

It was obvious that the effect of soaking seeds in rice false smut balls cell-free extract (RFSBCFE) on seed germination \% was higher than soaking in spore suspension, being 68.14 and 93.48, respectively (Tables 1 and 2). Data presented in Table (2) show some differences when seeds were soaked in (RFSBCFE). Complete germination of healthy seeds was recorded. Whereas, soaked seeds in RFSBCFE gave percentage of germination ranged from 20 to 93.33. Sakha 101 and Giza 171 recorded the same highest seed germination \%, followed by Super 300 and Sakha 108, while Giza 178, Giza 182 and Giza 181, respectively recorded the least values. Shoot and root length for some cultivars was observed to be higher than check treatment. For shoot length, Super 300, Sakha 108 and Sakha 104 , respectively were higher than Giza 182 which recorded the least length (1.88) followed by Sakha 101 (2.19). Shoot length of treated Sakha 108 was higher than the check treatment. As regard root length, Giza 182 was more affected (2.20) followed by Giza 178 (2.83), while, Sakha 108, Sakha 104 and super 300, respectively recorded the highest lengths exceeding that of the control treatments. RFSBCFE affected length of shoot and root of all the tested cultivars. Brown colored malformations of both shoot and root were observed in the two treatments for all the tested rice cultivars.

Table 1. Effect of soaking seeds of nine rice cultivars in spore suspension of Ustilaginoidea virens on seed germination \%, shoot and root lengths $(\mathrm{cm})$

\begin{tabular}{|c|c|c|c|c|c|c|c|}
\hline \multicolumn{2}{|c|}{ Cultivar } & \multicolumn{2}{|c|}{ Germination\% } & \multicolumn{2}{|c|}{ Shoot length $(\mathrm{cm})$} & \multicolumn{2}{|c|}{ Root length (cm) } \\
\hline 1 & Sakha 101 & $100 \mathrm{a}$ & $96 d$ & $4.01 \mathrm{~h}$ & $2.42 \mathrm{~L}$ & $8.1 \mathrm{~b}$ & $2.55 n$ \\
\hline 3 & Sakha 108 & $100 \mathrm{a}$ & $94.66 \mathrm{e}$ & $4.48 \mathrm{f}$ & $3.05 \mathrm{k}$ & $7.96 \mathrm{c}$ & $3.31 \mathrm{~L}$ \\
\hline 4 & Giza 171 & $100 \mathrm{a}$ & $98.66 \mathrm{~b}$ & $6.84 a$ & $4.36 \mathrm{fg}$ & $10.49 \mathrm{a}$ & $4.29 \mathrm{i}$ \\
\hline 5 & Giza 178 & $100 \mathrm{a}$ & $97.33 \mathrm{c}$ & $4.87 \mathrm{e}$ & $3.40 \mathrm{i}$ & $7.55 \mathrm{e}$ & $3.47 \mathrm{k}$ \\
\hline 7 & Giza 182 & $100 \mathrm{a}$ & $92 \mathrm{f}$ & $4.28 \mathrm{~g}$ & $3.16 \mathrm{jk}$ & $5.74 \mathrm{~g}$ & $4.86 \mathrm{~h}$ \\
\hline 8 & Super $\mathbf{3 0 0}$ & $100 \mathrm{a}$ & $94.66 \mathrm{e}$ & $6.00 \mathrm{c}$ & $3.23 \mathrm{j}$ & $7.58 \mathrm{e}$ & $3.97 \mathrm{j}$ \\
\hline 9 & Hybrid 1 & $100 \mathrm{a}$ & $92 \mathrm{f}$ & $6.01 c$ & $2.22 \mathrm{~m}$ & $7.82 \mathrm{~d}$ & $2.86 \mathrm{~m}$ \\
\hline & Mean & $100 \mathrm{a}$ & $93.48 \mathrm{~b}$ & $5.23 \mathrm{a}$ & 3.24 b & $7.45 \mathrm{a}$ & $3.68 \mathrm{~b}$ \\
\hline
\end{tabular}

In a column, means followed by a common letter (s) are not significantly different at the $5 \%$ level by DMRT

Table 2. Effect of soaking seeds of nine rice cultivars in RFSBCF extract of Ustilaginoideavirens on seed germination \%, shoot and root lengths $(\mathrm{cm})$

\begin{tabular}{|c|c|c|c|c|c|c|c|}
\hline & & \multicolumn{2}{|c|}{ Germination\% } & \multicolumn{2}{|c|}{ Shoot length $(\mathrm{cm})$} & \multicolumn{2}{|c|}{ Root length $(\mathrm{cm})$} \\
\hline & & Control & Treated seeds & Control & Treated seeds & Control & Treated seeds \\
\hline 1 & Sakha 101 & $100 \mathrm{a}$ & $93.33 \mathrm{~b}$ & $3.40 \mathrm{~m}$ & $2.19 \mathrm{q}$ & $11.79 \mathrm{a}$ & 5.931 \\
\hline 2 & Sakha 104 & $100 \mathrm{a}$ & $80.00 \mathrm{e}$ & $7.76 \mathrm{a}$ & $4.06 \mathrm{i}$ & $8.58 \mathrm{~h}$ & $9.05 f$ \\
\hline 3 & Sakha 108 & $100 \mathrm{a}$ & $85.33 \mathrm{~d}$ & $3.26 n$ & $4.14 \mathrm{~h}$ & $8.84 \mathrm{~g}$ & $10.28 d$ \\
\hline 4 & Giza 171 & $100 \mathrm{a}$ & $93.33 \mathrm{~b}$ & $6.37 \mathrm{~b}$ & $3.87 \mathrm{j}$ & $11.19 \mathrm{~b}$ & $8.31 \mathrm{i}$ \\
\hline 5 & Giza 178 & $100 \mathrm{a}$ & $20.00 \mathrm{i}$ & $4.66 \mathrm{e}$ & $2.49 p$ & $7.66 \mathrm{j}$ & 2.830 \\
\hline 6 & Giza 181 & $100 \mathrm{a}$ & $44.00 \mathrm{~g}$ & $4.47 f$ & 3.080 & $10.58 \mathrm{c}$ & $4.64 n$ \\
\hline 7 & Giza 182 & $100 \mathrm{a}$ & $34.66 \mathrm{~h}$ & $3.61 \mathrm{k}$ & $1.88 \mathrm{r}$ & $7.17 \mathrm{k}$ & $2.20 p$ \\
\hline 8 & Super 300 & $100 \mathrm{a}$ & $86.66 \mathrm{c}$ & $5.12 \mathrm{~d}$ & $4.37 \mathrm{~g}$ & $7.74 \mathrm{j}$ & $8.78 \mathrm{~g}$ \\
\hline 9 & Hybrid 1 & $100 \mathrm{a}$ & $76.00 \mathrm{f}$ & $5.39 \mathrm{c}$ & 3.511 & $9.30 \mathrm{e}$ & $5.06 \mathrm{~m}$ \\
\hline & Mean & $100 \mathrm{a}$ & $68.14 b$ & $4.89 \mathrm{a}$ & $3.29 \mathrm{~b}$ & $9.20 \mathrm{a}$ & $6.34 \mathrm{~b}$ \\
\hline
\end{tabular}

In a column, means followed by a common letter (s) are not significantly different at the 5\% level by DMRT

\section{Toxin identification using LC MS/MS:}

Five isomers of ustiloxin were detected in the prepared extract sample. The identified isomers of ustiloxin were compared with their corresponding standard at retention times: 8.93, 8.51, 8.95, 9.08 and 8.87 min for ustiloxin $A(M+, 674.3)$, B (M+, 646.2), $C(M+, 559.2), D(M+, 495.2)$ and $F(M+, 467.2)$, respectively. The fragmentation patterns for the main ions were observed at 187.2, 181.2, 181.1, 192.2 and $192.1 \mathrm{~m} / \mathrm{z}$, respectively, for isomers A, B, C, D and F, respectively (Table 3 and Figure 2).

Table 3. Separated isomers of ustiloxin at LC MS/MS

\begin{tabular}{|l|l|l|l|}
\hline Isomer & Precursor ion $\mathbf{( m / z )}$ & Product ion $\mathbf{( m / z )}$ & Rt $(\mathbf{m i n})$ \\
\hline A & 674.3 & 187.2 & 8.93 \\
\hline B & 646.2 & 181.2 & 8.51 \\
\hline C & 559.2 & 181.1 & 8.95 \\
\hline D & 495.2 & 192.2 & 9.08 \\
\hline F & 467.2 & 192.1 & 8.87 \\
\hline
\end{tabular}


A

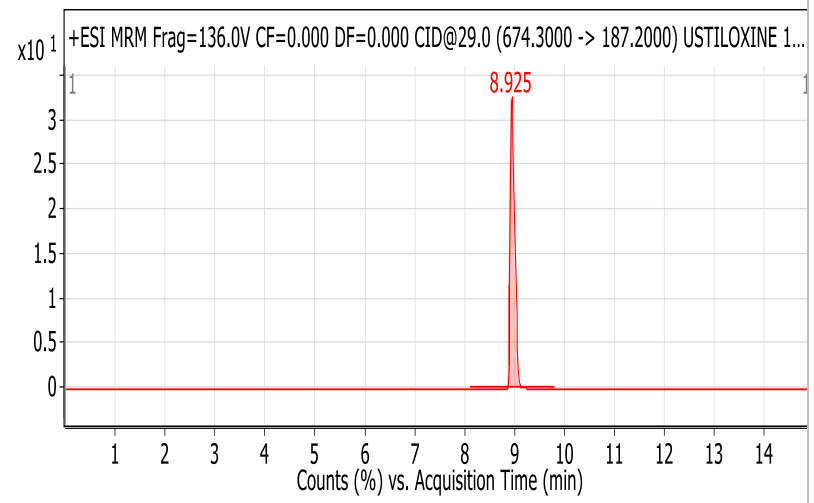

B

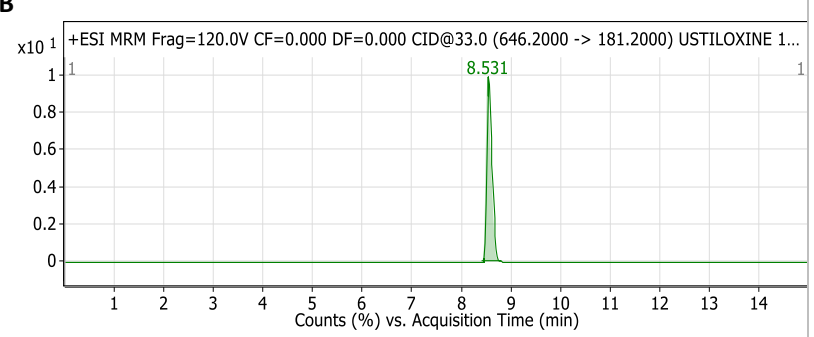

C

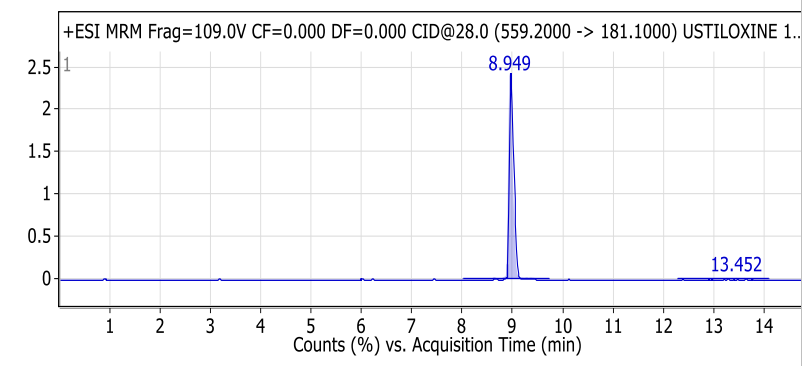

D

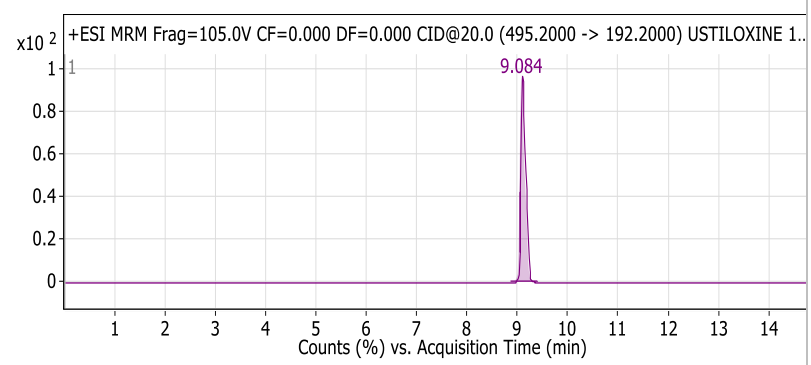

F

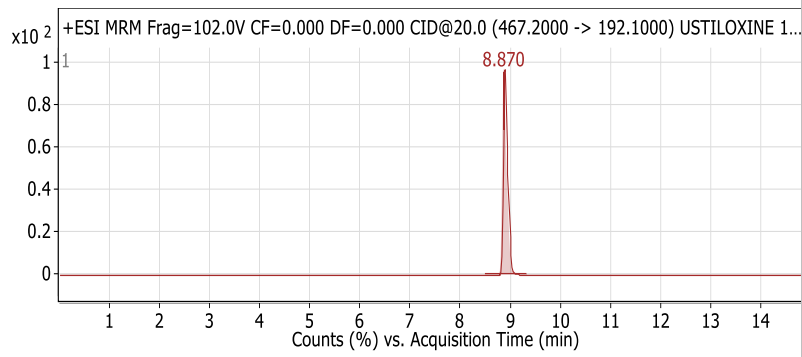

A1

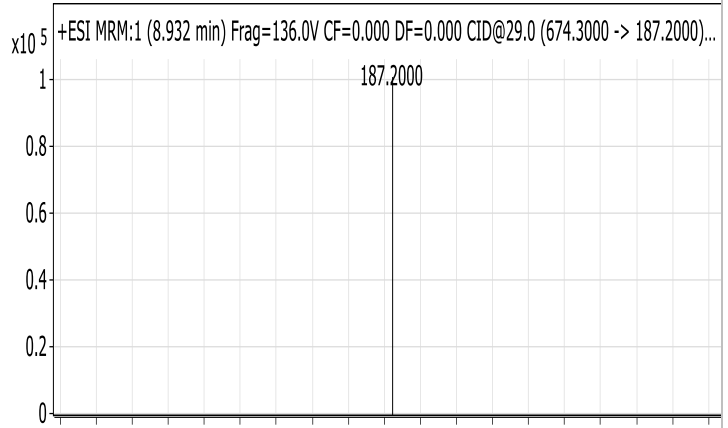

179180181182183184185186187188189190191192193194195196 Counts vs. Mass-to-Charge (m/z)

B1

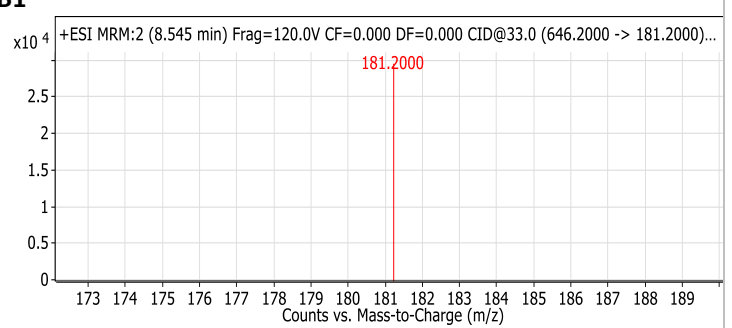

C1

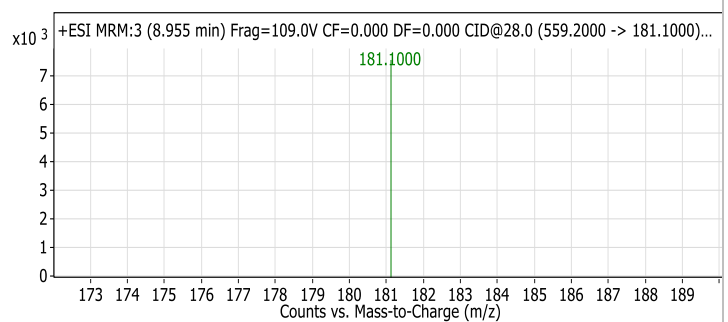

D1

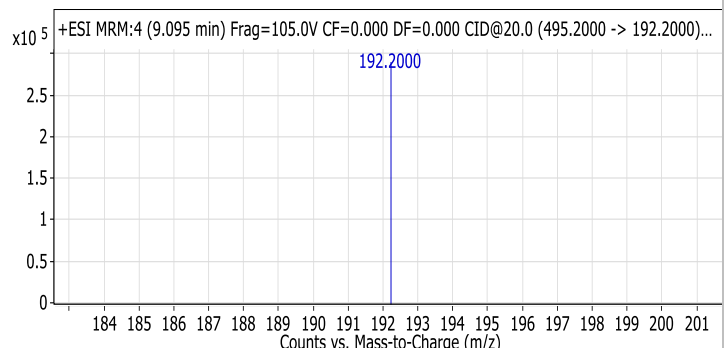

F1

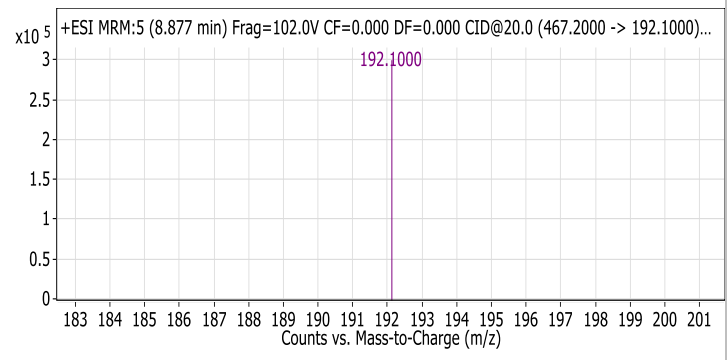

Fig. 2. Illustrating chromatograms (A-F) for ustiloxin isomers; A, B, C, D and F, and their corresponding ion patterns (A1-F1) 


\section{Toxicity of rice false smut balls in feeding rats:}

Signs of toxicity: No apparent signs of toxicity were noticed and no mortality occurred.

Weights of male albino rat's liver and kidney:

Data in Table (4) indicate that rats fed on rice false smut balls of $U$. virens at all concentrations showed no significant change in the weight of liver and kidney comparing those of control rats.

Table 4. Liver and kidney weights of male albino rats fed on contaminated rations with RFSBs for fourteen successive days.

\begin{tabular}{|c|c|c|c|c|}
\hline \multirow{2}{*}{$\begin{array}{c}\text { RFSB concentration } \\
\text { (\%) }\end{array}$} & \multicolumn{3}{|c|}{ Liver } & \multicolumn{2}{c|}{ Kidney } \\
\cline { 2 - 5 } & weight (g) & \% to control & $1.57 \mathrm{a}$ & 108.27 \\
\hline $\mathbf{1}$ & $7.46 \mathrm{a}$ & 113.37 & $1.61 \mathrm{a}$ & 11.03 \\
\hline $\mathbf{5}$ & $7.46 \mathrm{a}$ & 113.37 & $1.59 \mathrm{a}$ & 109.65 \\
\hline $\mathbf{1 0}$ & $6.29 \mathrm{~b}$ & 95.59 & $1.47 \mathrm{a}$ & 101.37 \\
\hline Control & $6.49 \mathrm{~b}$ & 98.63 & $1.45 \mathrm{a}$ & 100 \\
\hline
\end{tabular}

Values in each column having the same superscript letter(s) are not significantly different $(p>0.05)$.

Alterations in hepatic function parameters:

Table (5) indicates that $U$. virens increases the activity of ALT and AST as well as bilirubin level in rats treated with 5 , 10, and $25 \%$, whereas the aforementioned biomarkers remained unaltered in concentration $1 \%$. On the contrary, $U$. virens reduced serum albumin level of treated rats in a concentration-dependent manner. The hepatic deleterious effects were greater with increasing concentrations of $U$. virens.

Table 5. Serum aminotransferases (ALT and AST), albumin and bilirubin of male albino rats fed on contaminated rations with RFSBs for fourteen successive days.

\begin{tabular}{|c|c|c|c|c|}
\hline \multirow{2}{*}{ RFSBs concentration (\%) } & \multicolumn{2}{|c|}{$\operatorname{ALT}(U / L)$} & \multicolumn{2}{|c|}{ AST (U/L) } \\
\hline & Activity & $\%$ to control & Activity & $\%$ to control \\
\hline 1 & $53.33 \mathrm{~d}$ & 98.76 & $65.66 \mathrm{c}$ & 105.90 \\
\hline 5 & $79.00 \mathrm{c}$ & 146.30 & $80.00 \mathrm{~b}$ & 129.03 \\
\hline 10 & $117.33 b$ & 217.28 & $79.33 \mathrm{~b}$ & 127.95 \\
\hline 25 & $199.33 \mathrm{a}$ & 369.13 & $130.66 \mathrm{a}$ & 210.74 \\
\hline \multirow[t]{3}{*}{ Control } & $54.00 \mathrm{~d}$ & 100.00 & $62.00 \mathrm{c}$ & 100.00 \\
\hline & \multicolumn{2}{|c|}{ Albumin (gm /dl) } & \multicolumn{2}{|c|}{ Bilirubin (mg/dl) } \\
\hline & Level & $\%$ to control & Level & $\%$ to control \\
\hline 1 & $3.11 \mathrm{~b}$ & 91.47 & $0.56 \mathrm{bc}$ & 109.80 \\
\hline 5 & $2.94 \mathrm{c}$ & 86.47 & $0.61 \mathrm{~b}$ & 119.60 \\
\hline 10 & $2.88 \mathrm{c}$ & 84.70 & $0.69 a$ & 135.29 \\
\hline 25 & $2.43 \mathrm{~d}$ & 71.47 & $0.73 \mathrm{a}$ & 143.14 \\
\hline Control & $3.40 \mathrm{a}$ & 100.00 & $0.51 \mathrm{c}$ & 100.00 \\
\hline
\end{tabular}

Values in each column having the same superscript letter(s) are not significantly different $(p>0.05)$.

Effect on renal function parameters:

Table (6) shows that $U$. virens elevated serum levels of both urea and creatinine of treated rats in a concentration-dependent manner.

Table 6. The concentration of urea and creatinine in serum of male albino rats fed on contaminated rations with RFSBs for fourteen successive days.

\section{RFSBs concentration (\%)}

\begin{tabular}{|c|}
\hline 1 \\
\hline 5 \\
\hline 10 \\
\hline 25 \\
\hline Control
\end{tabular}

Values in each column having the same superscript letter(s) are not significantly different $(p>0.05)$.

\begin{tabular}{|l|l|l|}
\hline \multicolumn{2}{|c|}{ Urea (gm /dl) } & \multicolumn{2}{c|}{ Creatinine (gm /dl) } \\
\hline \% to control & Level & $\%$ to control \\
\hline 113.00 & $0.53 \mathrm{c}$ & 117.78 \\
\hline 118.68 & $0.59 \mathrm{~b}$ & 131.11 \\
\hline 127.63 & $0.64 \mathrm{~b}$ & 142.22 \\
\hline 149.59 & $0.72 \mathrm{a}$ & 160.00 \\
\hline 100 & $0.45 \mathrm{~d}$ & 100 \\
\hline
\end{tabular}

Effect on haematological parameters:

Data in Table (7) indicate a significant decrease of PCV and PLT of $U$. virens -treated rats at all concentrations. Whereas, RBC's, HGB, MCV and $\mathrm{MCH}$ were significantly reduced at all concentrations except at $1 \%$ comparing with the control group. On the other hand, WBC's recorded significant increases in $U$. virens -treated rats at all concentrations. In contrast, $M C H C$ remained unaltered. 
Table 7. Haematological changes in rats fed on contaminated rations with RFSBs for fourteen successive days

\begin{tabular}{|c|c|c|c|c|c|c|c|c|c|c|}
\hline \multirow{3}{*}{ Parameter } & \multicolumn{10}{|c|}{ RFSBs concentration (\%) } \\
\hline & \multicolumn{2}{|c|}{1} & \multicolumn{2}{|c|}{5} & \multicolumn{2}{|c|}{10} & \multicolumn{2}{|c|}{25} & \multicolumn{2}{|c|}{ Control } \\
\hline & Mean & $\begin{array}{c}\% \text { of } \\
\text { control }\end{array}$ & Mean & $\begin{array}{c}\% \text { of } \\
\text { control }\end{array}$ & Mean & $\begin{array}{c}\% \text { of } \\
\text { control }\end{array}$ & Mean & $\begin{array}{c}\% \text { of } \\
\text { control }\end{array}$ & Mean & $\begin{array}{c}\% \text { of } \\
\text { control }\end{array}$ \\
\hline RBC's $(\times 10 / \mu \mathrm{l})$ & $8.01 a$ & 96.38 & $7.64 b$ & 91.94 & $7.34 b$ & 88.33 & $6.94 c$ & 83.51 & $8.31 a$ & 100 \\
\hline HGB (g/dl) & $14.3 a$ & 95.97 & $13.53 b$ & 90.81 & $13.1 b$ & 87.92 & $12 c$ & 80.54 & 14.9a & 100 \\
\hline PLT $\left(10^{3} / \mathrm{mm}^{3}\right)$ & $612 b$ & 89.65 & $529.67 c$ & 77.59 & $485.67 d$ & 71.14 & $461.66 \mathrm{e}$ & 67.63 & $682.67 a$ & 100 \\
\hline PCV (\%) & $45.7 b$ & 95.87 & $44.13 b c$ & 92.57 & $43.2 c$ & 90.62 & $39.53 d$ & 82.92 & $47.67 a$ & 100 \\
\hline $\operatorname{MCV}\left(\mu m^{3}\right)$ & $59.45 a$ & 97.94 & $56.47 \mathrm{~b}$ & 93.03 & $55.14 b$ & 90.84 & $50.33 c$ & 82.91 & $60.7 a$ & 100 \\
\hline $\mathrm{MCH}(\mathrm{pg})$ & $18.39 a$ & 96.94 & $17.63 b c$ & 92.94 & $17.27 c$ & 91.03 & $16.57 d$ & 87.35 & $18.97 a$ & 100 \\
\hline MCHC (g/dl) & $31.07 a$ & 103.57 & $31.5 a$ & 105 & $30.83 a$ & 102.77 & $30.73 a$ & 102.43 & $30 a$ & 100 \\
\hline
\end{tabular}

Values in each column having the same superscript letter(s) are not significantly different $(p>0.05)$.

\section{DISCUSSION}

Rice false smut (RSFm) remained a minor disease of rice in Egypt, for a long time, but now it is a serious one. This disease caused losses at different districts at Sharkia governorates in 2001 growing season of 1.01 to $10.91 \%$, reducing the chaff percentage and 1000-grain weight (Attia, 2004). The problem is not limited to yield loss, but also the disease negatively affects seed germination. The present data show that a different reduction has been recorded compared with the check treatment in seed germination \% $(20 \sim 98.66)$, also in shoot and root length of the all tested cultivars at both treatments. This agrees with results of Sanghera, et al. (2012); Fu et al. (2017) and Nessa, et al. (2018) who proved that germination \% of healthy seeds was higher than RFSm contaminated seeds which were lower by $21.45 \%$ of smutted samples. Meanwhile, shoot and root lengths were reduced by $32.53 \& 22.65 \%$, respectively in comparison with non-smutted ones.

Two kinds of toxins were isolated and identified from rice false smut balls (RFSB) and the pathogen itself, namely ustiloxins and ustilaginoidins (Zhou et al., 2012; Fu et al., 2015a; Fu et al., 2015b and Menget et al., 2015). Ustiloxins are known to be toxic for plants and animals. In plant, ustiloxins could inhibit seed germination (Abbas et al., 2000 and Abbas et al., 2014), preventing growth of radical and plumule of rice, wheat and maize seeds during germination, causing abnormal swelling of seedling roots. Moreover, necrotic and dead tissues of duckweed seedlings (Lemna pausicostata) were noticed (Fu et al., 2015b). Also, the balls negatively affect grain quality (Sanghera, et al. 2012).

Results of the present study agree with previously noted ones, as roots of treated seeds (with spore suspension or RFSCFE) were brownish, lower in length and branches, malformed and dead after germination, likewise germ elongation was affected, on the contrary, healthy ones. Also, it was noticed that root length of the most susceptible cultivars in the field (Super 300, Sakha 108 and Sakha 104) was promoted when seeds were soaked in RFSCFE. So seed soaking in RFSCFE helps identification of the susceptible rice cultivars to false smut in a simple and efficient method. Noteworthy, that of radical growth was higher than for the plumule. This may be due to that roots had been directly adhered to toxin suspension and through absorption leading eventually to seedling death. These results are going with the findings of Chen et al., (2004); Gao et al., (2013) and Fu et al., (2017).

To detect ustiloxins inside rice false smut balls (RFSBs) or $U$. verins strains, many detection methods were established, e.g. HPLC, ic ELISA, LC-MS and LC-MS/MS (Miyazaki, et al., 2009; Ji et al., 2012; Shan et al., 2012; and Fu et al., 2015a and b). Till now, six kinds of Ustiloxins, Ustiloxins A, B, C, D, E and F have been isolated from the water extract of RFSB (Lin et al., 2018). The present study was aligned with this literature when using LC-MS/MS method, as sensitive and more selective, ustiloxins A, B, C, D, and F were detected in the water extract of RFSB.

RFSm disease causes damage in both yield and grain quality, besides mycotoxins accumulation, that is poisonous to plants, humans, and animals, thus threatens food and feed safety (Nakamura et al., 1994; Zhou, et al., 2012; Lu et al., 2014). So, toxicological profile of having RFSBs contaminated diets was studied in male albino rats by evaluating some hepatic, renal and haematological parameters.

No obvious toxicity signs or mortality occurred throughout the experimental duration in the treated rats at all tested concentrations. Moreover, liver and kidney weight had no significant difference comparing with the untreated rats. This was assured by Abbas et al. (1984) after 14 days of mouse feeding on $10 \%$ RFSBs contaminated diets compared with a ball- free ones. They did not observe a significant difference in weight gain, food consumption and visual symptoms of mouse behavior. On the other hand, Zhou et al., (2012) recorded many symptoms i.e., diarrhea, hemorrhage, poor growth, damage of liver, heart, and kidney as a result of feeding domestic animals on foodstuff contaminated with RFSBs.

The liver is the body organ responsible for toxic materials detoxification which enters the body (Balistreri and Shaw, 1987). So, liver can be used as an index for toxicity of xenobiotics. This can be detected by elevation of AST and ALT liver enzymes which are released in blood serum due to cell destruction which was proportionate to the intensive cellular aggression (Vinogradova et al., 1989; Ncibiet al. 2008 and Eissa and Zidan, 2010). Thus, both enzymes are an indicator of liver damage. Our results proved rising of these enzymes by increasing concentrations of RFSBs in contaminated diets at variance pure ones resulting in hepatic deleterious effects. Data proved another toxic effect on liver, hypoalbuminemia, due to reducing hepatic synthesis of albumin on treated rats (Burtis and Edward, 1994). Ustiloxins also in RFSBs cause stopping of rumination in cows and lesions of the liver tissues in rabbits, chickens, mice and other animals (Nakamura et al., 1993; Nakamura et al., 1994; Bai et al., 1997; Battilani et al., 2011 and Lu et al., 2014).

Data proved that by increasing RFSBs concentration in rat diets, the concentration of both blood urea and serum creatinine elevated. This might be caused by a reduction in glomerular filtration of the kidney and also reflects the dysfunction of the kidney tubules (Hayes, 1989 and Walmsley and White, 1994). When feeding domestic animals with the rice grains and foodstuff contaminated by RFSBs, they showed necrosis of kidney and bladder tissues in mice (Zhou et al., 2012). in vitro the renal tubular cells of rats were rapidly necrosed after single injection with Ustiloxins. Ustiloxins could inhibit microtubule proteins polymerization and cause abnormal mitosis resembling, which would lead to acute necrosis of renal tubular cells in mice (Koiso et al., 1994). 
The third effect of feeding contaminated rice grains with RFSBs on mice was haematological changes. In this study, there was a reduction in Rbcs (which are very important for oxygen transportation from lungs to tissues) and consequently, HGB, MCV and $\mathrm{MCH}$. That was due to Rbcs breakdown and/or the toxic effect on bone-marrow (responsible for Rbcs regeneration), (Harris, 1972 and Murray et al., 2007). Not only Rbcs were affected in this study but also white blood cells (WBCs) were increased. The presence of toxic substances in food of these rats induced damage of their tissues and severe disturbance of non-specific immune system, increasing white blood cells and increase stimulation of lymphopoiesis with increasing production of lymphocytes from lymph myeloid tissue (Das and Mukherjee, 2003). Data of many workers are in accordance with our data and recorded different toxic effects of having RFSBs contaminated diets on many domestic animals.

Gao (1992) indicated, at daily consumption, the lethal dose was $0.14-0.17 \mathrm{~g}$ RFS grains/ $1 \mathrm{~kg}$ weight of animal body, which recorded $37.5 \%$ mortality rate of rock roosters causing an inability of hens to lay eggs and ovarian atrophy. While feeding ducks with $5 \%$ RFS contaminated grains could cause hepatomegaly. Moreover, feeding pigs with $0.5 \%$ infected rice grains of RFS mixed with the feedstuff resulting in reducing pigs' growth rate and pathological changes of liver, kidney, spleen, ovarian hyperemia and fetal malformation (Shang et al., 1985 and Huang et al., 2019). Feeding animals with infected rice grains of RFS causes severe dehydration and exhaustion resulting in $71.12 \%$ death rate (Wu, 2004).

\section{Conclusion}

$U$. virens that causes rice false smut affects seedling vigor when treated with either its spores or RFSBCFE. Five Ustiolxins (A, B, C, D and F) have been detected in RFSBCFE which are poisoning for health of both human and animals. So we should modify our screening machines to prevent passage of any smutted balls to keep safe. Keeping in mind, cultivation of resistant cultivars and good screening before planting is the best procedure to avoid these problems. Besides, the ability to use seed soaking in RFSBCFE method to screen resistant cultivars before planting.

\section{Funding: Not applicable.}

Conflict of Interest: The authors declare no conflict of interest

\section{REFERENCES}

Abbas, H. K., Cartwright, R. D. , Windham, G. L. , Xie, W., Shier, W. T. \& Mirocha, C. J.(2000). The Presence of mycotoxins and fungi in rice and corn in the southern United States. Bulletin of the Institute for Comprehensive Agricultural Sciences, Kinki University, (8),23-28.

Abbas, H.K., Mirocha, C.J. \& Shier, W.T. (1984).Mycotoxins produced from fungi isolated from foodstuffs and soil: Comparison of toxicity in fibroblasts and rat feeding test. Applled and Environmental Microbiology,(48), 654-661.

Abbas, H.K., Wayne T. S., Rick, D. C. \& Gabe L. S. (2014 ). Ustilaginoidea virens Infection of Rice in Arkansas: Toxicity of False Smut Galls, Their Extracts and the Ustiloxin Fraction. American Journal of Plant Sciiences,(5), 3166-3176.

Attia, M. M. M (2004). Rice false smut (Ustilaginoidea virens) in Egypt. Journal of Plant Diseases and Protection, 111(1), 71-82.

Bai, Y., Wang, S., Liu, X., Shi, S., Jiang, B. \& Liu, S. (1997). Studies on the toxin of rice false smut (Ustilaginoidea virens). Liaoning Agricultural Sciences, (1), 30-33.

Baite, M.S. \& Sharma, R.K. (2015). Isolation technique and culture conditions of false smut pathogen (Ustilaginoidea virens) on rice. Indian Phytopathology, 68(1), 50-55.

Balistreri, W. F. \& Shaw, L.M. (1987). Liver function.In "Fundamentals of Clinical Chemistry". 3rd ed. TietzNB (ed.). Saunders Company. Philadelphia, London, Toronto. pp. 729-761.

Battilani, P., Gualla, A., Dall'Asta, C., Pellacani, C., Galaverna, G., Giorni, P., Caglieri, A., Tagliaferri, S., Spadaro, D., Pietri, A., Dossena, A., Marchelli, R., Gullino, M.L. \& Costa, L.G. (2011) Phomopsins: an overview of phytopathological and chemical aspects, toxicity, analysis and occurrence. World Mycotoxin Journal, (4), 345-359.

Burtis, C. \& Edward, A. (1994)."Clinical Chemistry".2nd ed. Vol. 2, Saunders Company. Printed In U.S.A., pp: 1354-1374.

Chen, M.J., H.u., DW \& X.u., Y (2004). Activity assay antiserum preparation and cellular localization of ustiloxins. Acta Biologiae Experimentalis Sinica, 37(4),310-314.

Das, B.K. and Mukherjee, S.C. (2003). Toxicity of cypermethrin in Labeorohita fingerlings: biochemical, enzymatic and hematological consequences. Comparative Biochemistry and Physiology, (134), 109-121.

Duncan, B.D (1955). Multiple range and Multiple F-test. Biometrics, (11),1-42.

Eissa, F.I. \& Zidan, N.A. (2010).Haematological, biochemical and histopathological alterations induced by abamectin and bacillus thuringiensis in male albino rats. Acta Biologica Hungarica, (61), 33-44.

Fu, R., Wang, J., Chen, C., Gong, X. \& Lu, D. (2017).Effect of crude toxins of Ustilaginoidea virens on rice seed germination. African Journal of Microbiology Research, 11(32), 1267-1273.

Fu, X., Wang, A., Wang, X., Lin, F., He, L., Lai, D., Liu, Y., Li, Q.X., Zhou, L. \& Wang, B. (2015b). Development of a monoclonal antibody-based icELISA for the detection of ustiloxin $B$ in rice false smut balls and rice grains.Toxins, (7), 3481-3496.

Fu, X., Wang, X., Cui, Y., Wang, A., Lai, D., Liu, Y., Li, Q.X., Wang, B. \& Zhou, L. A (2015a). Monoclonal antibody-based enzyme-linked immunosorbent assay for detection of ustiloxinA in rice false smut balls and rice samples. Food Chemistry, (181), 140-145.

Gao, D., Tang, S., Chen, Y. \& Li, Y. (2013). Correlation research of false smut pathogen (Ustilaginoidea virens) toxin and rice varieties' resistance. Hunan Agricultural Sciiences, (3), 16-17.

Gao, J. (1992). Toxicity to chichen and rabbit of rice false smut grains. Plant Protection, 18(10), 52-54.

Harris, J.W., (1972). Seasonal variation in some haematological characteristics of Ranapipens. Comparative Biochemistry and Physiology, (43), 975-89.

Hayes, A.W. (1989). "Principles and Methods of Toxicology".Raven Press.2nd edition, New York.

Huang, S., Liu, L., Wang, L. \& Hou, Y. (2019). Research on advance of rice false smut Ustilaginoidea virens (Cooke) Takah Worldwide: Part II. Studies progress on the pathogen and its toxin of $U$. virens. Journal of Agricultural Science, 11(15), $251-262$.

Ji, F., Cao, H., Xu, J., Yin, X. \& Shi, J. (2012). Simultaneous quantitative determination of ustiloxin A and ustiloxin D in rice grains by highperformance liquid chromatography-tandem mass spectrometry. Chinese Journal of Rice Science, (26), $246-250$.

Koiso, Y., Li, Y., Iwasaki, S., Hanaoka, K., Kobayashi, T., Sonoda, R., Fujita, Y., Yaegashi, H. \& Sato, Z. (1994). Ustiloxin, antimitotic cyclic peptides from false smut balls on rice panicles caused by Ustilaginoidea virens. Journal of Antibiotics, 47(7),765-773.

Li, W.L., Li, L.Y., Feng, A.Q., Zhu, X.Y. \& Li, J.X. (2013). Rice false smut fungus, Ustilaginoidea virens, inhibits pollen germination and degrades the integuments of rice ovule. American Journal of Plant Sciences, (4), 2295-2304.

Li, Y., Koiso, Y., Kobayashi, H., Hashimoto, Y. \& Iwasaki, S. (1995). Ustiloxins, new antimitotic cyclic peptides: interaction with porcine brain 
tubulin. Biochemical Pharmacology, (49), 1367-1372

Lin, X.Y., Bian, Y.F., Mou, R.X., Cao, Z.Y., Cao, Z.Z., Zhu, Z.W. \& Chen, M.X. (2018). Isolation, identification, and characterization of Ustilaginoidea virens from rice false smut balls with high ustilotoxin production potential. Journal of Basic Microbiology, 58(8),670678.

Lu, S., Sun, W., Meng, J., Wang, A., Wang, X., Tian, J., Fu, X., Dai, J., Liu, Y., Lai, D.\& Zhou, L. (2015). Bioactive bis-naphtho- $\gamma$-pyrones from rice false smut pathogen Ustilaginoidea virens. Journal of Agricultural and Food Chemistry, (63), 3501-3508.

Lu, S., Tian, J., Sun, W., Meng, J., Wang, X., Fu, X., Wang, A., Lai, D., Liu,Y. \& Zhou, L. (2014). Bisnaphtho- $Y$-pyrones from fungi and their bioactivities.Molecules, 19(6),7169-7188.

Meng, J., Sun, W., Mao, Z., Xu, D., Wang, X., Lu, S., Lai, D., Liu, Y., Zhou, L. \& Zhang, G. (2015). Main Ustilaginoidins and their distribution in rice false smut balls. Toxins ,(7), 4023-4034.

Miyazaki, S., Matsumoto, Y., Uchihara, T. \& Morimoto, K. (2009).High-performance liquid chromategraphic determination of Ustiloxin A in forage rice silage. Journal of Veterinary Medical Science, 71(2), 239-241.

Murray, R.K., Granner, D.K., Mayes, P.A. \& Rodwell, V.W. (2007). In: Harper's Illustrated Biochemistry. International 26th Edition, The McGraw-Hill Companies, Inc. pp: 46-47.

Nakamura, K. I., Izumiyama, N., Ohtsubo, K., Koiso, Y. \& Iwasaki, S. (1993). Apoptosis induced in the liver, kidney and urinary bladder of mice by the fungal toxin produced by Ustilaginoidea virens. Mycotoxins, (38), 25-30.

Nakamura, K. I., Izumiyama, N., Ohtsubo, K., Koiso, Y., Iwasaki, S., Sonoda, R. \& Sato, Z. (1994). "Lupinosis"-like lesions in mice caused by ustiloxin, produced by Ustilaginoieda virens: A morphological study. Natural Toxins, 2(1), 22-28.

Ncibi, S., Othman, M.B., Akacha, A., Krifi, M.N. \& Zourgi, L. (2008) Opuntia ficus indica extract protects against chlorpyrifos-induced damage on mice liver. Food and Chemical Toxicology, (46),797-802.

Nessa, B. (2017). Rice false smut disease in Bangladesh: Epidemiology, Yield Loss and Management. PhD thesis, Department of Plant Pathology and Seed Science, Sylhet Agricultural University, Sylhet, Bangladesh.

Nessa, B., Dipti, S.S., Salam, M.U., Haque, A.H.M.M., Biswas, J.K., Kashem, M.A. \& Kabir, M. S. (2018). Seed germination and grain quality of rice as affected by false smut disease. Bangladesh Rice Journal,22 (1), 1-7.

Sanghera, G. S., Ahanger, M.A., Kashyap, S. C., Bhat, Z. A., Rather, A. G. \& Parray, G. A. (2012). False smut of rice (Ustilaginoidea virens) under temperate agro-climatic conditions of Kashmir, India. Elixir Bio Technology,(49), 9827-9831.

Shan, T.J., Sun, W.B., Liu, H., Gao, S., Lu, S.Q., Wang, M.G., Sun, W.X., Chen, Z.Y., Wang, S. \& Zhou, L.G. (2012). Determination and analysis of Ustiloxins A and B by LC-ESI-MS and HPLC in false smut balls of rice. International Journal of Molecular Sciences, (13),11275-11287.

Shan, T., Sun, W., Wang, X., Fu, X., Sun, W. \& Zhou, L. (2013). Purification of Ustiloxins A and B from rice false smut balls by Macroporous Resins. Molecules, (18), 8181-8199.

Shang, B., Xu, S. \& Wang, Y. (1985). Experiment of perniciousness to swine of rice false smut (Ustilaginoidea virens). Zhejiang Agricultural Sciences, (1), 35-37.

Takahashi, M., Ashizawa, T., Yamanaka, N., Arai, M. \& Takahashi, Y. (2012). Pathogenic isolates of Ustilaginoidea virens differ greatly in their production of Ustiloxin A in rice false smut balls. Japanese Journal of Phytopathology, (78),305-308.

Vinogradova, L.F., Mirzoian, Zh.A., Kharlitskaia, E.V. \& Beketova, T.P. (1989). Experimental antioxidant therapy in toxic liver damage from CCl4 and chloxyl, Patologicheskaia Fiziolgiia i Eksperimentalnaia terapiia. Ter.,(4), 52-56.

Walmsley, R.N. \& White, G.H. (1994)."A Guide to Diagnostic Clinical Chemistry". 3rd ed., Oxford Blackwell Scientific Publication, London, Edinburgh, Boston, pp: 321-347.

$\mathrm{Wu}, \mathrm{Y}$. (2004). Treatment of toxic livestock and poultry with rice false smut (Ustilaginoidea virens) toxin by using integration of traditional Chinese medicine and Western medicine. Medicine Journal of Chinese Veterinarian, (5), 31-32.

Xiaoxiang, F.u., Wang, A., Wang, X., Lin, F., He, L., Lai,D., Liu,Y., Li, Q. X., Zhou, L. \& Wang, B. (2015). Development of a Monoclonal AntibodyBased icELISA for the detection of Ustiloxin B in rice false smut balls and rice grains.Toxins, (7), 3481-3496.

Zhou, L., Lu, S., Shan,T., Wang, P., Sun, W., Chen, Z. \& Wang, S. (2012). Chemistry and biology of mycotoxins from rice false smut pathogen. In Mycotoxins: Properties, Applications and Hazards. Melborn, B.J.,Greene, J.C., Eds.; Nova Science Publishers: New York, NY, USA,; pp. 109-130

Zhou, Y., Xie, X., Zhang, F., Wang, S., Liu, X., Zhu, L., Xu, J., Gao, Y. \& Li, Z. (2014). Detection of quantitative resistance loci associated with resistance to rice false smut (Ustilaginoidea virens) using introgression lines. Plant Pathology, (63), 365-372.

\begin{tabular}{|l|l|l|} 
Copyright: (C) 2021 by the authors. Licensee EJAR, EKB, Egypt. EJAR offers immediate open access to \\
its material on the grounds that making research accessible freely to the public facilitates a more \\
global knowledge exchange. Users can read, download, copy, distribute, print or share a link to the \\
complete text of the application under Creative Commons BY-NC-SA International License.
\end{tabular}


تأثير سموم الفطر Ustilaginoidea virens على إنبات حبوب الأرز ومخاطرها على التغذية منى مصطفى صالح1* و نور الهدى عبد الودود زيدان2

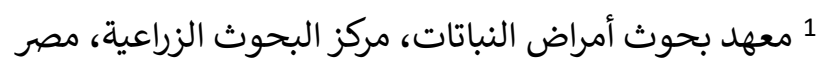

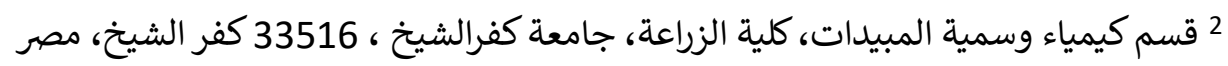

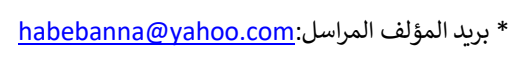

\section{الملخص العربى}

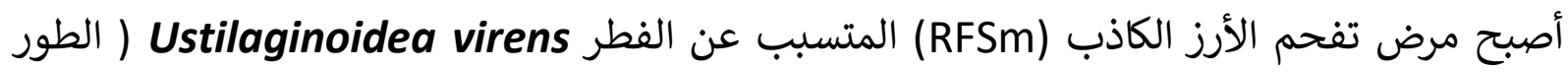

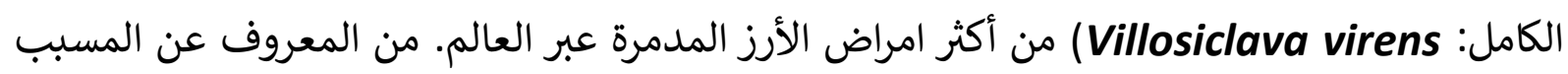

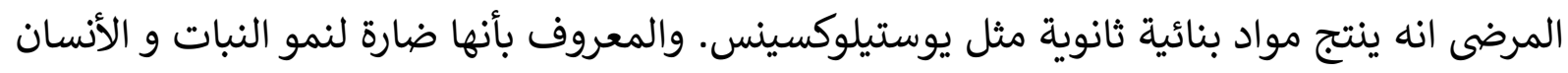

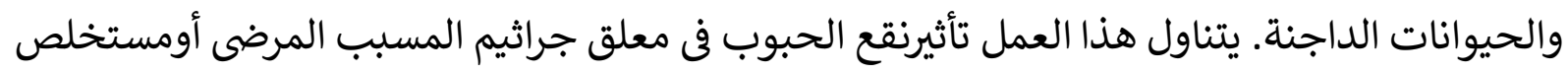

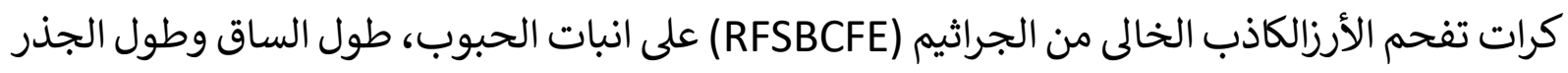

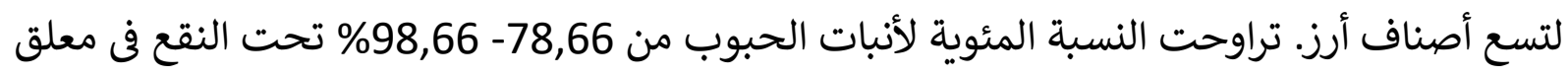
الجراثيم. بينما تراوحت من 20-

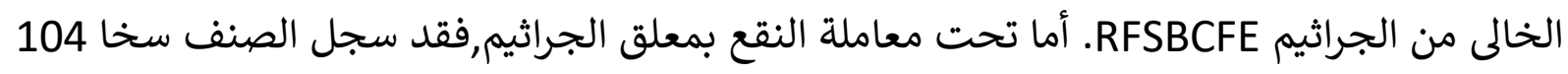

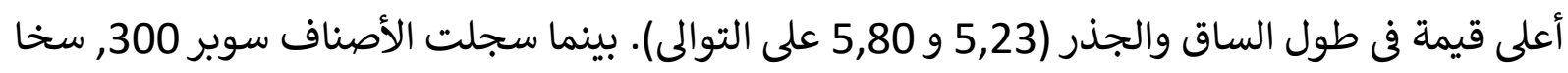

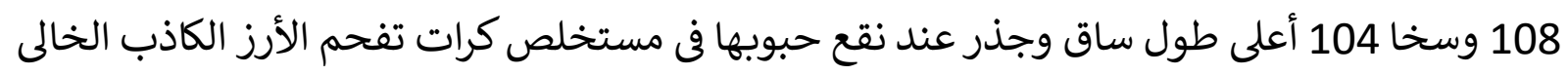

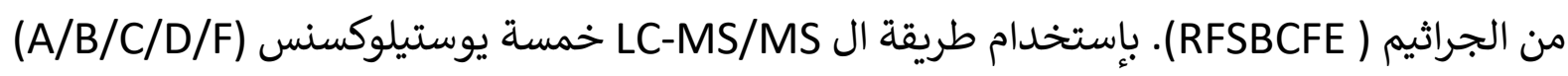

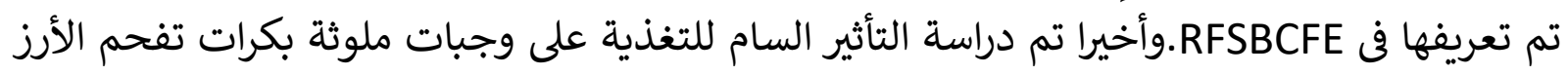

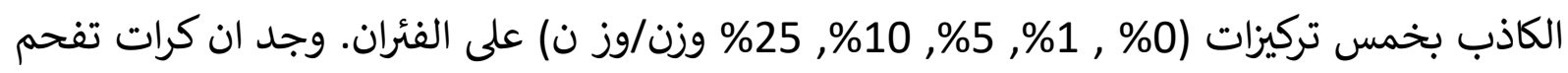

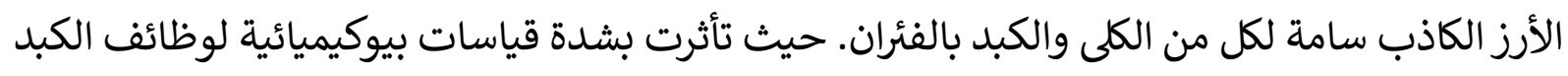

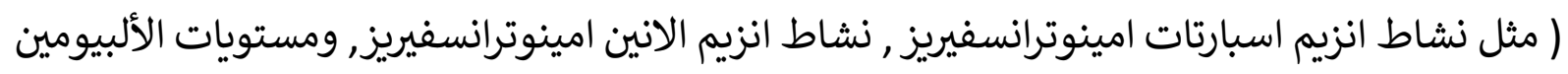

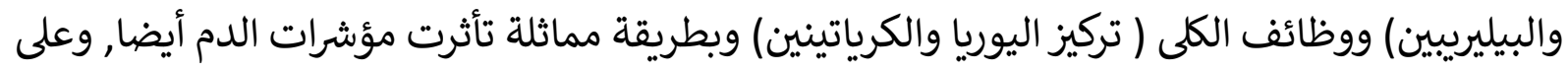

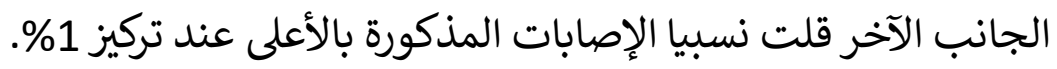
الكلمات المفتاحية: تفحم الأرز الككاذب، السمية النباتية، UC-MS / MS ،Ustiloxins، مخاطر التغذية 